DOI: https://doi.org/10.30525/978-9934-26-108-4-10

Olha Shulha

Doctor of Economic Sciences, Associate Professor, Associate Professor of the Department of Management and Marketing State University of Intelligent Technologies and Telecommunications

\title{
POTENTIAL AND DIRECTIONS OF DEVELOPMENT OF THE AGRICULTURAL SECTOR OF UKRAINE IN THE CONDITIONS OF THE COVID-19 PANDEMIC: CURRENT SITUATION, CHALLENGES AND PROSPECTS
}

\section{Summary}

The state and contradictions of the development of the agricultural sector of the national economy are investigated. Challenges at the micro-, macroand global levels for the agricultural sector in the context of the COVID-19 pandemic have been identified. It is noted that the main problems for the domestic agricultural sector in a pandemic were: reducing the purchasing power of the population, limiting the functioning of agri-food markets during quarantine, complicating the logistics of agricultural products. It is established that changes in the markets of countries that are major importers of agricultural products from Ukraine (China, India, the EU, Turkey, Egypt) in a pandemic will have the greatest impact on the development of Ukraine's agricultural sector. It is concluded that among all sectors of the national economy, agriculture is the least affected by quarantine restrictions. It is shown that small and medium-sized farms suffer the greatest losses in a pandemic. The tasks facing agricultural enterprises and the state in the conditions of a pandemic are determined. The strategic directions of agricultural policy in Ukraine are indicated. 


\section{Introduction}

The agricultural sector is a system-forming element of any economy, which ensures the development of technologically related sectors of the economy and forms the socio-economic foundations of rural development, the principles of food and, within certain limits, economic, environmental and energy security. One job in agriculture creates conditions for the organization of 10 jobs in other areas of production, and one currency received in the industry, gives the opportunity to get 12 units in other industries; rural areas are a place of rehabilitation of the country's inhabitants, and the rural population is a talisman of national customs and traditions. In all countries, agriculture remains an important factor in food security. Thus, the stable development of the domestic agricultural sector is a guarantee of food independence of the state, the basis of social and political stability in the country, an important tool for sustainable development and poverty reduction. At the same time, increasing the export potential of the agricultural sector is a guarantee of a rapid overcoming of the country's trade and balance of payments deficit.

According to the World Bank, the growth of gross domestic product, which is due to the growth of agriculture, is at least twice as effective in reducing poverty than the growth of gross domestic product from other industries, and it is the innovative development of this sector provides a large reduction in rural poverty in recent years in many countries around the world. In addition, the calculations of American scientists show that one percent of additional products produced in the agricultural sector, provides an increase in production of industrial infrastructure by $2.5 \%$, respectively, manufacturing by $1.4 \%$, transport services - by $0.33 \%$, adequate trade - by $2.7 \%$. Therefore, accelerating the growth rate of agricultural production on the basis of increasing its competitiveness is a priority of economic policy.

$11.9 \%$ of value added is created in the agricultural sector of Ukraine, $18 \%$ of the population is employed in agricultural production. In addition, the share of the rural population is 31\% [9]. Trade in agricultural products is one of the main sources of foreign exchange earnings in the country. Exports of agricultural products give Ukraine up to $40 \%$ of foreign exchange earnings [8]. It follows that we are an industrial and agricultural country in which the agricultural sector still continues to play an important role both economically and socially. However, today the progressive development of the domestic agricultural sector is hampered by new problems, challenges caused by the COVID-19 pandemic.

In 2020-2021, the subjects of the Ukrainian agri-food market faced new challenges caused by COVID-19. In particular, the main problems for the agricultural sector in a pandemic were the decline in the purchasing power of the population, limiting the functioning of agri-food markets during quarantine, complicating the logistics of agricultural products. Under such conditions, some domestic agricultural enterprises, which did not have a sufficient margin of financial stability, became very vulnerable to any 
changes in production and sales. That is why the study of the main challenges for the agricultural sector of Ukraine in the context of the COVID-2019 pandemic and the search for adequate solutions to respond to them are extremely important.

\section{Part 1. Status and current challenges of sustainable development of the national agricultural sector}

In the agricultural sector of Ukraine, there are three socio-economic systems: 1) personal farms; 2) mostly diversified agricultural enterprises, and 3) highly specialized, highly marketable agricultural holdings. In general, there are more than 47 thousand enterprises in the agricultural sector [12, p. 171], among which the predominant organizational and legal form is farms, which account for $70.6 \%$ of all businesses in this sector. However, the number of farms has been declining in recent years. They own and use 4.7 million hectares of agricultural land. One farm has 154.6 hectares of agricultural land. Their share in the total volume of agricultural production in 2018 was $9.3 \%$, including crop production $-11.9 \%$, and livestock production $2.1 \%$. That is, they specialize mainly in the cultivation of crop products, which are dominated by crops such as millet, buckwheat, barley, sunflower, soybean and rapeseed [9].

Potential subjects of agricultural production are private farms, of which there are more than 4.1 million units in Ukraine. They use 6.3 million hectares [11, p. 55]. Their share in the total volume of agricultural production is $41.2 \%$, including crop production $-37.2 \%$, livestock production $-52.5 \%$ [9]. Private farms produce $98.1 \%$ of potatoes, $85.6 \%$ of vegetables, $78.4 \%$ of fruits and berries, almost $73 \%$ of milk and $34.9 \%$ of meat. Thus, as we see, personal farms are a stabilizing link of the economy, which not only ensures food security of the state, but also generates income for the rural population.

At the same time, in the structure of production of these categories of farms there is a tendency to specialization and concentration of agricultural production. Today, economically unprofitable products for agricultural enterprises have moved to households. It is in the farms of the population that most of the livestock and almost all the production of labor-intensive crops are now concentrated.

Another important point in the development of the agricultural sector of Ukraine is that today the real owners of land and income from it, in most cases, are corporate structures, or so-called agricultural holdings. That is, the consequence of the transformation of land relations was the formation of two opposite models of land use - latifundist and parcel.

The first model began to take shape in the late 1990s, but these processes intensified after 2004. It is accompanied by the concentration of hundreds of thousands of hectares of agricultural land in the hands of agricultural holding companies, the prosperity of shadow schemes with land, speculation on lease rights, buying and raiding agricultural enterprises, the destruction of local 
agricultural ecosystems, the elimination of nonprofit under fodder crops, violation of crop rotations, degradation of agricultural lands, etc. Their presence in the agricultural sector leads to structural distortions in land use, crop structure and agricultural production, as well as the raw material nature of exports.

Agricultural holdings operate as business structures whose main purpose is to increase equity. Such structures specialize in the production of highly profitable types of agricultural products. They produce and sell about $50 \%$ of winter wheat, more than half of corn, canola, a third of sunflower, more than $80 \%$ of poultry meat [7, p. 38]. According to some estimates, there are already about 300 large (over 10,000 hectares) and 30 very large (over 50,000 hectares of land) agricultural holdings in Ukraine. At the disposal of a large group of holdings is up to a third, and the largest - up to $10 \%$ of the leased area of agricultural land [1, p. 191-192].

Agricultural holdings have already absorbed more than 6,000 agricultural enterprises (almost $40 \%$ of their total number) and 7.8 million hectares of agricultural land (this is $38 \%$ of all cultivated areas by agricultural enterprises). Most of them work in several (from 3 to 15) regions and have there from 10 to 60 agricultural enterprises, powerful services [1, p. 258]. Their use of highly efficient tillage systems leads to an increase in rural unemployment. In particular, the number of employees in such corporations varies from 2 to 5 people per 100 hectares of agricultural land, depending on the region. Accordingly, they provide employment for only $1 / 5$ of the working rural population, which indicates their low social efficiency. This situation is due to the fact that to work with modern technologies they need highly qualified specialists who often live in cities [7, p. 30-31].

In accordance with the above, we can identify the following features of the functioning of agricultural holdings in the agricultural sector of the economy: vertical integration in the form of property integration; concentration of a significant land bank; use of land bank mainly on a lease basis; high economic efficiency based on the results of financial and economic activities; the key specialization is crop production; in terms of scale and territorial dispersion, they are interregional (present in almost all regions of Ukraine); registration of agricultural holdings in offshore with the participation of Ukrainian capital allows them to provide preferential tax conditions; additional activities of agricultural holdings are the distribution of agricultural machinery, fertilizers and plant protection products; the presence of a significant diversified loan portfolio in most agricultural holdings in Ukraine is mainly due to the attraction of international credit resources and so on.

The main negatives of the functioning of agricultural holdings in the agricultural sector of Ukraine are the following:

1) deformations in agriculture. The agricultural holdings grow mainly highyielding crops that deplete the soil (corn, canola, sunflower). Crops of the latter reach $20 \%$ of arable land at an acceptable rate of $9-12 \%$, in some areas sunflower is used up to a third of crops. Instead, the area under fodder crops is 
reduced. Almost half of large farms do not have livestock, so the land is not fertilized with organic matter. Soil fertility decreases. In order to obtain high yields and high profits, they use the processes of genetic modification and chemicalization of land;

2) there were serious distortions between agriculture and the food industry;

3) there is a hidden purchase and sale of land and property shares under the guise of rent.

However, we can note some positives from their presence: they provide an inflow of investment in the industry, offer higher rents to landlords, demonstrate higher management efficiency due to the scale of agricultural production, use the capabilities of modern mechanisms to attract foreign capital, using the practice of IPO (placement of enterprises' securities on leading stock exchanges), they are vertically, agro-industrial and trade integrated, they effectively implement innovations, enter the foreign market.

That is, as we can see, if the positives from the activities of agricultural holdings are mainly economic, the negatives are mainly social and environmental. Among the economic negatives there are distinguished the oppression of other forms of management, the destruction of competition and markets, excessive concentration of land, violation of the established proportions of management; among the social there are their alienation from the problems of the village, and among the ecological there are the processes of chemicalization and genetic modification, which pose a threat to the environment and man.

It follows from the above that latifundist-type economic entities unconditionally give priority exclusively to their economic interests, ignoring all other aspects of both agricultural and rural development. For them, land is only a productive resource for income, and rural areas - a place for the production of high-yielding agricultural products. They lack a sense of social responsibility to the rural community and a desire to preserve rural areas.

The second model of land use is parcel, represented by private farms, which have limited opportunities to address land lease, purchase of equipment, plant protection products, mineral fertilizers, as they currently do not have access to state support and loans from commercial banks. Many of them are not able to provide sufficient income for members of their farms. Therefore, they are forced to look for additional places to earn money.

At the same time, today we can say that among the individual peasant farms a contingent of farms is being formed that can replenish the farming system. In particular, the processes of differentiation of households by the presence of human, land, biological (livestock and poultry), technical resources and the level of revenues from sales are intensifying. The consequence of this is the growth of shares of farms, which, on the one hand, accumulate resources and produce mainly marketable products, and on the other hand, manufacture products only for their own consumption. At the same time, the share of farms occupying an intermediate position is declining. 
The human factor in the development of personal peasant farms is now generally weakening. This is primarily due to a decrease in the number of rural households and a deterioration in the age structure of their members. In particular, there is a decrease in the share of young people (people aged 18-29) and an increase in the share of people of retirement and adulthood. The deterioration of the labor supply of households is evidenced by the distribution of rural households depending on the number of people in their composition. More than 50\% of households operating in rural areas consist of 1-2 members, among whom the majority are older than working age [3, p. 12]. It is established that the largest volumes of marketable agricultural products are produced in households of different ages and those consisting of middle-aged people; the smallest - in the farms of pensioners and youth without children; youth farms with children occupy an intermediate position between them.

In addition, there is a tendency to concentrate land resources in the group of farms with a land use of more than 1 ha: the share of farms with land plots with a total size of more than 1 ha is growing, and the total area of their land use is increasing. The share of households with the smallest (up to $0.25 \mathrm{ha}$ ) land plots is also slightly increasing, i.e., households are polarizing according to the size of the land they use. The larger size of land use indicates the ability to produce marketable products. Thus, land plots with an area of up to 0.25 hectares in rural areas are used by $23.2 \%$, and plots over 1 hectare almost $46 \%$ of households [3, p. 18].

The process of differentiation of households is observed in relation to their production of livestock products. In recent years, more and more households are abandoning keeping animals. First of all, households consisting of persons of retirement age and those who find it particularly difficult or unprofitable to keep cattle are deprived of animals. The main share of livestock and poultry is accounted for by households with a land use area of more than 1 ha. In addition, farms with a land use area of more than 1 hectare are better than the rest, and provided with technical means. The analysis of rural households by the level of income from the sale of agricultural products shows, on the one hand, an increase in the stratum of households with a commodity direction of production, on the other hand, the share of purely consumer farms is increasing.

In accordance with the above, we can conclude that today in Ukraine there is a bimodel structure of agriculture: in parallel, large-scale commodity production on the basis of newly established agricultural enterprises and small-scale production in private farms and small farms. The first model can be called industrial, and the second can be called traditional. In addition, the agricultural business in Ukraine is becoming increasingly specialized and differentiated in size. There is a tendency to concentrate land in the use of fewer and fewer businesses.

In the absence of norms of responsibility of tenants for non-compliance with scientifically sound land use systems, environmental problems have 
become threatening. Assessment of soil condition shows the accelerated development of such types of their degradation as erosion, loss of soil humus, reduction of nutrients, over-compaction, waterlogging, acidification, etc. In degraded soils, under the influence of a decrease in the content of organic matter and other factors, their structure is destroyed, the living conditions of microorganisms deteriorate, which leads to a decrease in the productivity of agricultural lands.

There is a disproportion in the ratio between the main batteries. Due to the reduction of livestock, the application of organic fertilizers has decreased. In recent years, it has remained at a minimum. The application of organic matter to the soil per hectare decreased in agricultural enterprises compared to 1990 by 9-10 times. Ecologically permissible ratios of arable land, natural forage lands and forest plantations have been violated, which has a negative impact on the sustainability of agricultural landscapes. Plowing of lands in corporations reached $93.9 \%$ of agricultural lands, low-productive lands, riparian meadows, pastures and sloping lands were involved in cultivation. Intensive use of agricultural land leads to a decrease in soil fertility due to wind and water erosion.

However, at the same time, with its favorable geographical location, climatic conditions and fertile soils, Ukraine has a great chance to become one of the main suppliers of quality organic products in the world. International experts believe that Ukraine can easily increase exports, especially to the EU, of organic sunflower seeds, soybeans and cereals. No less promising areas are increasing organic production and export of fruits and berries, walnuts, herbs, aromatic plants, honey, high-protein crops used for animal feed. However, this must be accompanied by a guarantee of security of supply, a competitive price level and compliance with the EU requirements for the content of genetically modified organisms. Although we should not forget about the main obstacles to expanding this area of agriculture: the lack of a national system of product certification, the cost of the certification procedure, which is usually carried out by foreign certification bodies, lack of state support in the transition from traditional to organic agriculture.

The peculiarity of the demographic situation of rural settlements is the combination of the scale of depopulation with the progressive aging of the rural population and the deterioration of other qualitative indicators. There is a constant decrease in the number of rural residents and an increase in the intensity of this process. The rate of rural population decline has almost doubled over the last decade compared to the previous one.

The dynamics of the age structure of the rural population indicates a decrease in the share of people younger than able-bodied. Today, almost one in three villagers is retired. Rural areas are characterized by a high level of demographic aging, which is accompanied by an increase in the demographic burden of people of childbearing age. The main reason for the decrease in the total birth rate in villages is the insufficient level of wages and incomes of the 
rural population to ensure its economic reproduction, often the lack of objects of employment, the lack of social infrastructure in villages and so on. Wages in the agricultural sector are the lowest among all sectors of the national economy, so its level does not provide not only the maintenance and upbringing of children, but also the restoration of the efforts of agricultural workers themselves. Under such conditions, the birth rate in villages has become crisis-ridden, and families with two children are becoming rare.

However, the main social problem that has arisen as a result of agricultural transformations is real and hidden unemployment. The number of employees has been declining in recent years in both agricultural enterprises and farms, as well as households. The number of vacancies for such unemployed is limited. If on average in the country 10 people apply for one vacancy, then among agricultural workers this indicator amounts to 53 people [7, p. 39].

As a result of unsatisfactory working conditions and rising unemployment in rural areas, there is an increase in labor migration. More than a third of villagers work in cities and other settlements. A significant part goes abroad to earn money. As a result, the birth rate decreases. Already today, depopulation of villages has become a sign of demographic and settlement crisis.

The growth of nominal incomes of peasants in recent years has not reduced the differentiation of rural residents in terms of welfare. The low level of income of peasants has a negative effect on their food security. Most of the calories they get from plant products. For most basic foods, actual consumption does not reach the level of rational norms established by the Ministry of Health of Ukraine. The largest gap between actual and rational consumption was observed for milk and dairy products, meat and meat products, fish and fish products. Only for bread, potatoes and oil (until 2015), actual consumption usually exceeds the rational norm.

Thus, in the agricultural sector of Ukraine there are contradictions between forms of ownership and forms of management; contradictions in the development of the social sphere of the village (financing on a residual basis); contradiction between producers, intermediaries and consumers; availability of price scissors between industrial and agricultural products; contradiction between the concentration of agricultural production and land ownership in the hands of agricultural holdings and the reduction of the rural population and falling living standards, etc.

The specifics of the above contradictions are: first, the formation of a bimodel structure of agriculture (large-scale commodity production on the basis of newly formed agricultural enterprises and small-scale production of households and small farms) with a significant share of small-scale structure (peasant); secondly, the formation of two diametrically opposed land use models - latifundist and parcel; third, the presence of differentiation in the commercialization of households (the presence of commercial, consumer and mixed farms), etc. 
The main forms of manifestation of economic contradictions in the agricultural sector of Ukraine are: depletion of large land areas with commercially attractive crops (sunflower, rapeseed, etc.) by agricultural holdings; commodity crisis of agricultural economy (in the structure of commodity production the share of grain and sunflower increased and production of fodder and livestock products decreased), structural crisis (decline of fodder and livestock industries), investment crisis (imperfection of the financial and credit system, political and economic instability); intensification of recessionary processes in agriculture (increased number of uncultivated privatized land shares); availability of intermediary structures, etc.

The main manifestations of social contradictions in the system of agrarian relations are: rising levels of real and hidden unemployment in rural areas; strengthening migration processes; depopulation; demographic and settlement crisis; reduction of human capital in rural areas; deterioration of living standards and welfare of peasants; food poverty in rural areas, etc.

Another important aspect of the analysis of the state of the domestic agricultural sector is the analysis of the commodity structure of foreign trade in agricultural and food products. The analysis of the commodity structure for 2015-2020 shows that the largest share in exports is occupied by products of plant origin, and in imports instead - ready-made food products. Thus the first place in the Ukrainian export of agricultural products is occupied by corn (it is exported to China, Egypt, Turkey, Israel), on the second place - sunflower oil (it is exported to India, the EU countries, China), on the third place wheat (its importers is Egypt, Bangladesh, Turkey). Accordingly, changes in the markets of these countries in a pandemic will have the greatest impact on the development of Ukraine's agricultural sector.

If we analyze foreign trade in agricultural and food products, it should be noted that in 2020-2021 there was a decrease only in exports of live animals and animal products, while the growth rate of imports in groups I-IV, according to the Ukrainian classifier of foreign economic activity, exceeded export growth.

It should be noted that agriculture is least affected by quarantine restrictions. Representatives of large agricultural holdings feel best in a pandemic, while small and medium-sized farms suffer the most. Among the administrative measures that took place during the quarantine and directly affected the development of agriculture, we should mention the closure of markets in March-May 2020. As a result of such actions, small producers, who are supposed to form the basis of agriculture, were deprived of the opportunity to sell their products. Given that it is in the food markets that the vast majority of early vegetables and berries are usually sold, this has caused problems with the sale of grown products, deprived consumers of food supplies and put small farmers and peasants in a difficult financial position. This process has also resulted in the bartering of relations in rural areas, which is one of the signs of the crisis in the industry. 
During quarantine, large retail chains and large purchasing firms increased prices for agricultural products (despite attempts by the state to regulate prices for certain groups of food products). This resulted in a decrease in demand from the population, as well as a gradual change in the structure of the industry, due to the reduction of agricultural production entities and, in particular, its sales. This is due to the excess of prices for agricultural products in Ukraine in April-May by $20-40 \%$ (by different food groups) compared to the EU countries [5].

The situation resulting from quarantine restrictions (as well as in the case of their repeated use to counter the second wave of the pandemic) contains threats related to the deterioration of food security in Ukraine, the destruction of small agricultural businesses, exacerbation of social tensions, shadowing of aggravating agricultural markets' opportunities for anti-epidemic control of this process, provokes an increase in prices for agricultural products in retail chains, stimulates its import.

Given these factors, farmers deprived of the opportunity to sell their own products and working capital will be much more flexible in the process of alienation of their own land, real estate and means of agricultural production. The consequence of this may be a further strengthening of monopolistic tendencies in agriculture. An alternative is to unite small farms to jointly seek solutions and counter the monopoly of large agricultural holdings [6].

Among the positive factors in the development of the coronavirus industry is the return of both skilled and unskilled workers, who can be involved in seasonal agricultural work and compensate for the traditional shortage of farms, including those located in Central and Western Ukraine. At the same time, in the long run, due to the coronavirus crisis, agricultural business will lose many jobs due to trends in maximum mechanization and automation of processes.

There is also the problem of «closing» many countries in terms of agricultural exports due to concerns about the level of personal food security. Due to the reduction of supply in the global food market, this has led to a global increase in prices for certain groups of goods, including wheat and flour.

At the same time, cheap oil and the coronavirus crisis will hit the prices of feed grain because they are directly related to energy prices through bioethanol, the raw materials for which are sugar cane and corn. Most bioethanol plants in the United States have stopped because it cannot compete at such low oil prices. To run them again you need to lower the price of corn. Accordingly, more corn will enter the feed markets, which are already oversaturated, as demand for meat has also fallen. Along with forecasts of falling demand for red meat, the decline in corn prices may be the largest, and this is precisely the main grain crop in Ukraine.

Therefore, the relevant Ministry must ensure that Ukraine maintains its leading position in the world and adapt the industry to the new conditions. In particular, due to climate change, it is necessary to develop irrigation systems in the central regions of Ukraine, and to increase the industry's profits - to 
reorient it to the production of finished products. The importance of irrigation is growing due to global climate change. Only the development of irrigation systems in the near future can increase the yield by 10 million tons per year and create an additional 200 thousand jobs [13].

Thus, all the challenges of the agricultural sector in the context of the COVID-19 pandemic can be divided into three groups [2]:

1. Challenges of the micro level (outbreaks of coronavirus infection in the enterprise, reducing the competitiveness of the enterprise, weakening financial stability);

2. Challenges at the macro level (restrictions on the export of agricultural products, reducing the stability of the monetary and financial system, etc.);

3. Global challenges. These include the likelihood of a long-term pandemic, restrictions on imports of products of the Ukrainian agro-industrial complex, a decrease in the purchasing power of the population of major importing countries.

Accordingly, the challenges facing agricultural enterprises in a pandemic are:

1. Establishing cooperation with contractors through telephone and electronic means;

2. Providing the possibility of storage in order to preserve the highest quality;

3. Reviewing the range of products in the direction of increasing the share of crop production;

4. Optimizing the use of energy resources, fuels and lubricants, finance, etc.

Thus, for the state to realize the agricultural potential of the domestic agricultural sector it is necessary to: implement the legislation on tax benefits for agricultural cooperatives, stimulate the development of irrigation systems, stimulate the production and export of finished goods (flour, oil, etc.), not only agricultural raw materials, etc [13].

\section{Part 2. Strategic directions of agricultural policy in Ukraine}

The conceptual model of economic policy of the state to resolve social and economic contradictions in the system of agricultural relations, in our opinion, should be based on the fact that it is impossible to build effective agricultural relations and form an effective system of motivation of labor and production without resolving contradictions in the system of land property relations. This is due to the fact that only by resolving the contradictions of land ownership relations it is possible to create conditions for resolving all other contradictions in the system of agricultural relations and, accordingly, to ensure an objective and regular course of development of the latter. Since the bearers of these contradictions are the subjects of agricultural relations, which are guided by their own interests, their resolution is possible only on the basis of coordination of the interests of the latter.

The function of reconciling interests should be taken over by the state. This must organize and direct the activities of individuals, social groups, and society as a whole, focusing on the satisfaction of public interests above all. 
This is due to the fact that without taking into account the interests of the system, the components of this system (subsystem) cannot work effectively. Violation of the subordination of interests by subsystems (for example, by land relations), as shown by world and domestic experience in the transformation of agricultural relations, harms the very system of agricultural relations, of which they are part. That is, the main function of the state is, on the one hand, to guarantee the protection of the rights of owners, and, on the other hand, to reasonably limit these rights.

The key principle of the conceptual model of economic policy of the state to resolve social and economic contradictions in the system of agricultural relations can be formulated as follows: since land is owned by the people, ownership should be limited to society (tendency to socialize the economy).

Therefore, in our opinion, the transformation of land relations in Ukraine at the first stage should be reduced to the spread of lease and cooperation. In the second stage, subject to the formation of appropriate institutional and macroeconomic conditions, over time we can expect an increase in the level of agricultural culture and financial solvency of peasants and farmers. And only after a sufficient mass of efficient landowners and land users in the countryside will be formed, it will be possible to completely lift the moratorium on the purchase and sale of agricultural land.

No less important direction of the agricultural policy of the state in the current situation is the growth of the level of marketability of personal farms. The strategy of further development of personal farms in Ukraine should be aimed at increasing the productivity and efficiency of their operation, primarily by providing them with state support, promoting their cooperation with each other and with agricultural enterprises, integration with processing and marketing enterprises.

The most rational directions of development of personal peasant farms are: 1) specialization of personal peasant farms on labor-intensive types of agricultural products; 2) cooperation of economic entities with each other and their integration with other forms of management in the production, procurement and sale of products, as well as with enterprises of the third sphere of the agro-industrial complex; 3) development of special programs at the state, regional and district levels, which would take into account the need for their specialization, cooperation and integration, etc.

It is also expedient to develop agricultural cooperation in Ukraine. After all, a cooperative, on the one hand, is an enterprise that performs certain business functions, guided by the economic interests of its owners, and on the other hand, it is a social entity in which those who cooperate find social protection, satisfying their economic interests. In addition, cooperatives contribute to rural development, as they create jobs and promote the skills of rural residents. Therefore, the creation of cooperatives is especially necessary in rural areas with a surplus of labor and economically backward areas, and for households, which are currently the leading producers of agricultural products. 
The need to promote the development of cooperation in rural areas is due to its advantages, in particular - the advantages of large production over small; limited capabilities of an individual producer to develop processes of concentration and specialization in order to increase the scale of a particular industry (i.e., cooperation provides opportunities for the development of processes of concentration and specialization of farms in the production of certain products by combining their efforts in the form of mutually beneficial cooperation); ensuring the realization of the material interest of employees in collective work; maintaining the scale of production and, at the same time, providing an effective motivational mechanism that combines individual, collective and general economic interests, etc.

In addition, world and domestic experience shows the inextricable link between the cooperative movement and the establishment of market economy principles, free exchange of goods, open competition and freedom of foreign economic activity. In view of this, cooperation is an indicator of the development of the market environment and the quality of its institutional support.

Unfortunately, the idea of cooperation in Ukraine «it does not work» is justified all over the world. This is due to the fact that, on the one hand, the regulations governing the activities of cooperatives «do not work», and on the other hand - the current tax system does not encourage farmers to create cooperatives. In our opinion, it is necessary to implement a system of political, legal and economic measures to intensify the cooperative movement, which provides for:

1) improvement of the current legislation in order to provide favorable conditions for the creation and development of various agricultural cooperatives (in particular, the transfer of cooperatives to the status of nonprofit organizations or at least granting them the status of agricultural producers); development at the legislative level of the organizational mechanism of state support for the establishment and operation of cooperatives in rural areas (but such state support should be long-term - at least 5-6 years); providing state aid in the amount of not less than $90 \%$ of the start-up capital; establishment of a system of benefits for the subjects of cooperation; introduction of a simplified taxation system;

2) demonopolization of the economy of the agricultural sector and the development of competitive market relations between its subjects (because in a monopoly of large capital blocks opportunities for competition from small producers, which in the long run limits the formation of effective agricultural cooperation between them);

3) improvement of mechanisms for providing state support to economic entities in the direction of not only equality and transparency in obtaining preferences, but also encouraging farmers to seek market means to increase their competitiveness through the development of agricultural cooperation;

4) popularization of advantages of association of small commodity producers of agricultural products in agricultural cooperatives among 
inhabitants of rural settlements; creation of advisory services at village and settlement councils in order to provide consulting and information services and practical assistance in their creation, etc.; promoting the formation of regional cooperation centers, in which, together with advisory services, advisory assistance would be provided to newly established cooperatives; organization of schools of cooperative leaders by training and accompanying small agricultural producers who aspire to unite in cooperatives.

In addition, it is necessary to promote the development of credit cooperation, because, as world practice shows, in the EU, China, India, South Korea, farmers meet their credit needs through their own cooperative and specialized government agencies. In view of this, it is necessary to amend the Laws of Ukraine «On Banks and Banking» No.2121-III dated 07.12.2000 and «On Cooperation» No. 1087-IV dated 10.07.2003 in the part concerning credit cooperatives and cooperative banks. It is also advisable to promote the development of wholesale markets for agricultural products and the creation of procurement points.

At the same time, the agricultural sector should develop such a form of intersectoral relations of self-employed entities for the transfer of knowledge and innovation as clusters. This requires the development of cluster organization and management of agro-industrial production. In particular, the spread of clusters in the agricultural sector is one of the most optimal ways to establish mutually beneficial and competitive relations between agricultural enterprises and institutions, organizations of related sectors of the economy. Their dissemination will create conditions for the growth of agricultural production and sustainable development of rural areas, ensuring a high standard of living for the rural population. Within the cluster, on the basis of integration and cooperative relations, agricultural, industrial and processing enterprises will adapt rapidly to competitive conditions, which is currently extremely important for the development of the agricultural sector of Ukraine.

In addition, in the context of European integration, Ukraine needs to develop its strategy of advanced development, which provides for the transition to widespread introduction of new equipment and technologies, improving production management based on information and communication technologies, mass improvement of professional skills and more. It is this path of development, which is based on the widespread use of resource-saving technologies, allows you to combine the reduction of production costs with increasing production, increasing its efficiency and obtaining a significant part of added value. This path of development is due to the fact that the Common Agricultural Policy of the European Union is aimed at increasing the income of agricultural producers by stimulating the introduction of innovative production, management and marketing measures that reduce costs and get a significant share of value added. In this way it is possible to ensure the growth of income and competitiveness of agricultural producers, 
especially small ones. This area of support is government assistance in creating a special image of the product or its special quality.

The issue of intensifying the innovative activity of agricultural enterprises is also relevant. However, the intensification of innovation processes in the agricultural sector requires significant funds from economic entities, which currently have limited financial resources. Therefore, in order to increase innovation activity in agriculture, a number of measures should be taken. Firstly, to promote the introduction of research and innovation in agriculture by providing tax incentives for businesses that use technology and imposing sanctions on those who use inefficient technology. Secondly, the development of innovation infrastructure on the principle of education-science-production and the creation of innovation-production clusters in agriculture. Thirdly, it is necessary to improve the legal framework (protection of intellectual property rights, the creation of patent courts) and increase the level of remuneration of employees of research and development, and fourthly, to raise awareness of farmers in the field of innovation.

In addition, it is necessary to use the world experience of state support of innovation activities of enterprises through the introduction of tax benefits such as, in particular, deferral of tax payments in the event of additional costs for innovation purposes; reduction of tax on the amount of increase in costs for innovation purposes; exemption from taxation of profits from the implementation of innovative projects for several years; preferential taxation of dividends received on shares of firms engaged in innovative activities; reduction of income tax rates in order to release reserve funds for research and development; reduction of income taxation in the amount of the cost of devices and equipment transferred to higher education institutions, research institutes and other innovative organizations.

Domestic agricultural policy on the management of rural areas requires rethinking, because they are the basis for the formation and operation of the main productive force of the agricultural sector of the economy - the agricultural producer. It is useful in this regard to study the experience of the EU countries and adapt their rural management practices to the realities of the domestic economy, which will further avoid the negative impact of domestic and foreign economic factors on rural areas. According to the experience of developed countries, the solution of socio-economic problems of rural development should take place in two main directions. The first direction is to move industrial, service and processing enterprises to the countryside. This will help solve the problem of unemployment in rural areas and improve the living standards of rural residents.

Since over time, as the technical and technological modernization of agricultural production, the need for specialists and agricultural workers will decrease, it is necessary to stimulate the development of small business and self-employment in rural areas (repairs, transport services, green tourism, sewing workshops). Support for start-ups should be a priority for authorities 
and local governments. This can be achieved through the establishment of advisory services at village and settlement councils, which would assist farmers in preparing documents for business registration, drawing up business plans, advising and teaching the basics of doing business, etc. In addition, it is necessary to ensure the development of labor-intensive industries, which will provide employment for a large number of unemployed in rural areas. It is also necessary to ensure the development and implementation of regional targeted programs for the development of rural employment.

The second direction of diversification of the rural economy involves the development of social infrastructure, which is a necessary prerequisite for «maintenance» of human and intellectual capital in rural areas. In particular, this is possible due to preferential taxation of income of agricultural producers who finance the maintenance of social infrastructure in rural areas, the introduction of compensation from the state budget costs to enterprises and organizations that ensure the development of rural social infrastructure, etc. to increase the volume of agricultural production, but also to create decent living and living conditions for the livelihood of the rural population.

\section{Conclusions}

Ukraine is one of the guarantors of food security in the world and has significant potential to increase agricultural production. In recent years, Ukraine ranks second in the world in terms of total grain exports. All the challenges of the agricultural sector development in the context of the COVID-19 pandemic can be divided into three groups: micro-level challenges (outbreaks of coronavirus infection in the enterprise, reduced competitiveness of the enterprise, weakening financial stability); macro-level challenges (restrictions on the export of agricultural products, reduced stability of the monetary and financial system, etc.); global challenges (probability of a longterm pandemic, restrictions on imports of domestic agricultural products, declining purchasing power of the population of major importing countries.

Accordingly, the tasks facing agricultural enterprises in a pandemic are: establishing cooperation with contractors through telephone and electronic communications; provide for the possibility of storage in order to preserve the highest quality; review the range of products in the direction of increasing the share of crop production; optimize the use of energy resources, fuels and lubricants, finance, etc. In turn, the tasks facing the state in a pandemic so that it can realize its agricultural potential include the following: to implement the legislation on tax benefits for agricultural cooperatives, to stimulate the development of irrigation systems, the production and export of finished goods, not only agricultural raw materials, etc.

The main strategic approaches to improving state support of the agricultural sector should be: directing state support to the agricultural sector to increase the competitiveness of agricultural products, stabilize the agricultural market and ensure the profitability of agricultural production; stimulating the increase of 
incomes of the population and directing their purchasing power to purchase, first of all, domestic products; greening of agricultural production in order to preserve ecosystems and achieve long-term productivity; stimulating employment and entrepreneurship development in rural areas; investing in research and innovative developments and promoting their implementation in agriculture; promoting poverty reduction and rural economic development, etc. That is, the strategy of state support of the agricultural sector should strengthen the social, environmental and innovation component.

\section{References:}

1. Haydutskyy P. I. (2015) Ahrarna reforma L. D. Kuchmy v Ukrayini [Agricultural reform of L.D. Kuchma in Ukraine]. Kyiv: TOV «Informatsiyni systemy». (in Ukrainian)

2. Dolbnyeva D. V. (2020) Vplyv COVID-19 na ekonomiku krayin svitu [The impact of COVID-19 on the economy of the world]. Problems of Economy, vol. 1, pp. 20-26.

3. Dopovid «Sotsialno-demohrafichni kharakterystyky domohospodarstv Ukrayiny u 2017 rotsi» [Report «Socio-demographic characteristics of households in Ukraine in 2017»]. Available at: http://www.ukrstat.gov.ua/ (accessed 10 June 2021).

4. Informatsiyno-analitychnyy portal APK Ukrayiny [Information and analytical portal of the AIC of Ukraine]. Available at: https://agro.me.gov.ua/ua (accessed 26 May 2021).

5. Karantyn yak mekhanizm monopolizatsiyi silskoho hospodarstva [Quarantine as a mechanism of monopolization of agriculture]. Available at: https://bit.ly/2CVHDJI (accessed 26 May 2021).

6. Karantyn yak poshtovkh dlya obyednannya malykh fermeriv i spilnoho poshuku rishen [Quarantine as a push to unite small farmers and work together to find solutions]. Available at: https://www.prostir.ua/?news=karantyn-yak-poshtovh-dlya-objednannyamalyh-fermeriv-i-spilnoho-poshuku-rishen (accessed 26 May 2021).

7. Borodina O. M., Zayats T. A., Kutsenko V. I. (2014) Kontseptualni zasady sotsialnoekonomichnoho rozvytku silskykh terytoriy [Conceptual principles of socio-economic development of rural areas]. Kyiv: DU IEPSR NAN Ukrayiny. (in Ukrainian)

8. Koronavirus, karantyn i posukha: chy bude Ukrayina $\mathrm{z}$ khlibom tsoho roku? [Coronavirus, quarantine and drought: will Ukraine have bread this year?]. Available at: https://www.bbc.com/ukrainian/features-52441162 (accessed 26 May 2021).

9. Ofitsiynyy sayt Derzhavnoyi sluzhby statystyky Ukrayiny [Official site of the State Statistics Service of Ukraine]. Available at: http://www.ukrstat.gov.ua/ (accessed 26 May 2021).

10. Petrukha S. V., Stakhov B. V. (2020) Suchasni vyklyky stalomu rozvytku ahrarnoho sektoru ekonomiky Ukrayiny: teoretyko-kontseptualni aspekty [Modern challenges to sustainable development of the agricultural sector of the economy of Ukraine: theoretical and conceptual aspects]. Ahrosvit, no. 8, pp. 49-71.

11. Prokopenko O. M. (ed.) (2016) Silske hospodarstvo Ukrayiny [Agriculture of Ukraine]. Kyiv: Derzhkomstat Ukrayiny. (in Ukrainian)

12. Prokopenko O. M. (ed.) (2017) Silske hospodarstvo Ukrayiny [Agriculture of Ukraine]. Kyiv: Derzhkomstat Ukrayiny. (in Ukrainian)

13. Ukrayinske silske hospodarstvo mozhe «vytyahty z kryzy» vsyu ekonomiku eksperty [Ukrainian agriculture can "pull out of the crisis» the entire economy - experts]. URL: https://www.radiosvoboda.org/a/ukrainian-apk-can-support-all-economy/31070474.html (accessed 2 June 2021). 